\title{
Evaluation of the Trophic Level of Kune and Vain Lagoons in Albania, Using Phytoplankton as a Bioindicator
}

\author{
Anni Koci Kallfa ${ }^{*}$, Fatbardha Babani, Ariana Ylli Kraja \\ Department of Biotechnology, \\ Faculty of Natural Sciences, University of Tirana, Albania \\ e-mail: a_koci@hotmail.com
}

Cite as: Koci Kalfa, A., Babani, F., Ylli Kraja, A., Evaluation of the Trophic Level of Kune and Vain Lagoons in

Albania, Using Phytoplankton as a Bioindicator, J. sustain. dev. energy water environ. syst., 2(1), pp 61-67, 2014, DOI: http://dx.doi.org/10.13044/j.sdewes.2014.02.0006

\begin{abstract}
Concentration of chlorophyll is an adequate parameter for assessing the trophic state of lagoon ecosystems. Objectives of this study are: selection of a system of bioindicators to enable a good qualitative evaluation of the trophic state of the lagoons and their dynamics; evaluation of seasonal water quality variability and comparison between lagoons. The trophic state of the lagoons is analysed every month over the year. Water samples are retrieved at four different sites (exact coordinates) each month, sites that are representative of different water circulation systems at each lagoon. The trophic level in the respective lagoons is thus assessed through selection of an adequate system of bioindicators, in order to observe the oscillations of the amount of chlorophyll and therefore to determine the level of eutrophication. Based on the above parameters, the comparison of the trophic state in these two lagoons has shown that they have different trophic states.
\end{abstract}

\section{KEYWORDS}

Kune and Vain lagoons, Lagoon ecosystem, Trophic state, Phytoplankton, Chlorophyll a

\section{INTRODUCTION}

The Kune and Vain lagoons of the Adriatic coast of Albania are situated on both sides of Drini river. Due to lack of sufficient maintenance of communication channels, as well as increase of intense agricultural practices along the coastline and around the lagoons, the water quality has worsened and therefore the attention of scientists and managers of natural resources has been focused recently on the assessment of the water quality and the means for improvement. The Kune lagoon communicates with the Adriatic Sea through a $22 \mathrm{~m}$ wide strait, while the Vain lagoon communicates with the sea through a 1,300 m long and 20-30 m wide canal, currently closed, and the Zaje-Drin canal, which can be opened to regulate balance between salty and non-salty waters [1].

Data on previous monitoring missions [2] indicates that the trophic levels in these two lagoons significantly differ, since they are separated by Drini river and do not communicate with one another. However, these two lagoons make up one ecosystem, which includes different components, from lagoons to alluvial forests, including agricultural land.

The variation in the trophic level between the two lagoons is thought to be related to the state of communication with the sea, outside sources of pollution [2], and the high amount of evaporation and lack of circulation, especially during summer months.

\footnotetext{
* Corresponding author
} 
In the Kune lagoon, station 1 is closest to the communication channel with the sea, while station 4 is the farthest (Figure 1). In Vain lagoon, station 1 is closest to communication with the sea and station 4 is closest to communication with the river that separates the two lagoons. Therefore, based on the approximation to the communication channels, a better trophic situation is expected in sampling stations 1 and 2 in Kune and 1 and 4 in Vain.
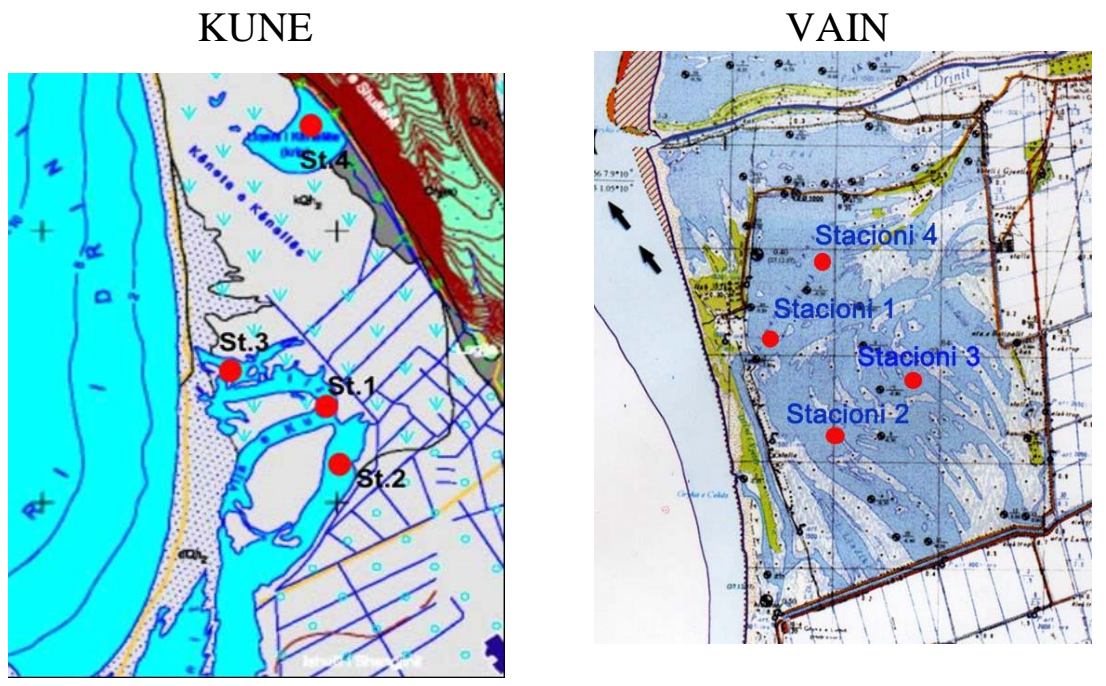

Figure 1. Kune and Vain lagoons and respective sampling stations

\section{METHODOLOGY}

The different chlorophyll and non-chlorophyll pigments associated with the photosystems all have different spectra. The content of chlorophyll $a, b, c$, carotenoids, phaeophyta, etc., is determined based on standardized spectrophotometric and fluorimetric methods [3].

The trophic state of the lagoons is analysed every month over the year 2010. Definition of the trophic state as oligotrophic, mesotrophic, eutrophic and hypereutrophic is based on a classification provided in literature. Based on chlorophyll content, the trophic level is grouped into four classes, from lowest to highest: oligotrophic ( $0-2.6$ $\mu \mathrm{g} / \mathrm{L})$, mesotrophic $(2.6-20 \mu \mathrm{g} / \mathrm{L})$, eutrophic $(20-56 \mu \mathrm{g} / \mathrm{L})$ and hypertrophic $(56-155+\mu \mathrm{g} / \mathrm{L})[4]$. Based on the data, rehabilitation measures are recommended in order to conserve and improve further the state and the general situation of the ecosystem.

Water samples are retrieved at four different sites (exact coordinates) each month (Figure 1), sites that are representative of different water circulation systems at each lagoon. Pigments are filtered, then extracted with aceton 90\%. Determination of pigments is performed based on the trichromatic method, using equations based on the maximums of absorption for each component: chlorophyll $a, b, c$ and carotenoids, in a spectrophotometer [5]. Based on the content of photosynthetic pigments, ratios of chlorophyll $a$ /chlorophyll $b$, chlorophyll $a /$ chlorophyll $c$, chlorophyll $b /$ chlorophyll $c$ and chlorophyll/carotenoids are calculated, in order to provide indication on the presence of types of microalgae in lagoon waters.

\section{RESULTS AND INTERPRETATION}

The trophic state of the lagoons is analysed every month over the year. Water samples are retrieved at four different sites (exact GPS coordinates) each month, sites that are representative of different water circulation systems at each lagoon. 
During this study, samples were collected at 4 sampling stations in the Kune lagoon and 4 sampling stations in Vain lagoon over a period of 4 months during year 2010. These stations are chosen such as to represent different water quality and trophic state, mainly based on the distance from communication canals. The exact coordinates are respected during each site monitoring visit. Samples are repetitively retrieved during the period April-October each year [5]. Concentration of chlorophyll $a$ and other phytopigments were assessed for each sample (Table 1).

Table 1. Content of photosyntethic pigments in Kune Lagoon

\begin{tabular}{ccccccc}
\hline \multirow{6}{*}{ July } & 2010 & $\begin{array}{c}\text { Chlorophyll } a, \\
{\left[\mu \mathrm{g} / \mathrm{dm}^{3}\right]}\end{array}$ & $\begin{array}{c}\text { Chlorophyll } b, \\
{\left[\mu \mathrm{g} / \mathrm{dm}^{3}\right]}\end{array}$ & $\begin{array}{c}\text { Chlorophyll } c, \\
{\left[\mu \mathrm{g} / \mathrm{dm}^{3}\right]}\end{array}$ & $\begin{array}{c}\text { Carotenoids, } \\
{\left[\mu \mathrm{g} / \mathrm{dm}^{3}\right]}\end{array}$ & $\begin{array}{c}\text { Phaeophitins } \\
{\left[\mu \mathrm{g} / \mathrm{dm}^{3}\right]}\end{array}$ \\
\hline \multirow{6}{*}{ August } & St 1 & 2.073 & 0.382 & 0.434 & 1.776 & 0.756 \\
& St 2 & 2.571 & 0.385 & 0.305 & 1.782 & 0.721 \\
& St 3 & 81.622 & 2.173 & 16.527 & 46.715 & 18.246 \\
& St 4 & 13.628 & 0.297 & 1.884 & 6.133 & 0.892 \\
\hline \multirow{6}{*}{ September } & St 1 & 2.107 & 0.148 & 0.289 & 1.809 & 0.531 \\
& St 2 & 2.155 & 0.267 & 0.309 & 1.646 & 0.294 \\
& St 3 & 9.64 & 0.759 & 1.817 & 5.51 & 0.927 \\
& St 4 & 3.231 & 0.514 & 0.462 & 2.415 & 0.275 \\
\hline \multirow{6}{*}{ October } & St 1 & 2.157 & 0.81 & 1.112 & 1.867 & 0.296 \\
& St 2 & 2.06 & 0.213 & 0.242 & 1.211 & 0.097 \\
& St 3 & 3.079 & 0.526 & 0.535 & 2.438 & 0.974 \\
& St 4 & 3.147 & 0.245 & 0.314 & 1.848 & 0.494 \\
\hline & St 1 & 1.794 & 0.352 & 0.587 & 1.433 & 0.267 \\
& St 2 & 1.695 & 0.34 & 0.515 & 1.391 & 0.538 \\
& St 3 & 2.674 & 0.34 & 0.735 & 2.008 & 0.168 \\
& St 4 & 1.532 & 0.27 & 0.44 & 1.173 & 0.117 \\
\hline
\end{tabular}

Based on previous data [5] in Kune lagoon the average chlorophyll $a$ content indicates a deterioration of the trophic conditions from 2002-2007 (Figure 2). This lagoon in general appears to be mesotrophic, but there are peaks (year 2007) when this lagoon has been eutrophic.

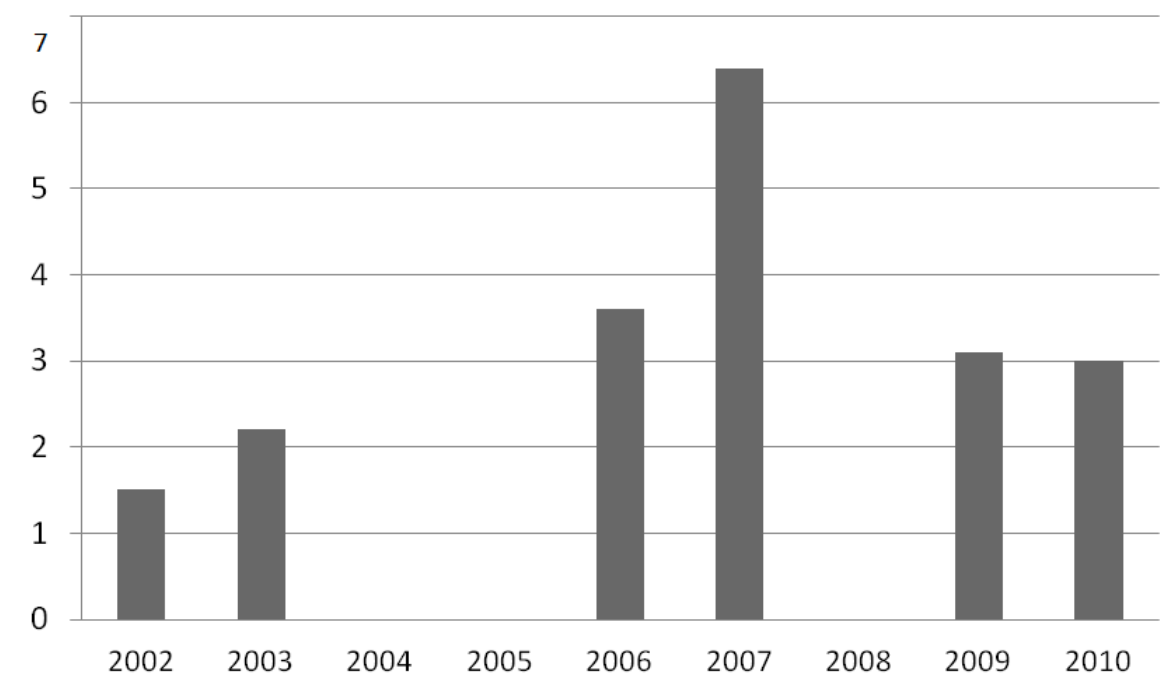

Figure 2. Variation in chlorophyll $a$ concentration in $\mathrm{mg} / \mathrm{m}^{3}$ over the years at the Kune lagoon [5] 
Over the last decade (Figure 2) Kune lagoon initially had a tendency for a trophic state increase in average, with a peak in year 2007, but afterwards the situation has improved. In general, Kune lagoon is in a mesotrophic state.

During 2010, there was noticed a high variation of chlorophyll $a$ content among sampling stations in Kune lagoon (Table 1). Stations 1 and 2 in general appear oligotrophic, while station 3 during the month of August resulted as hypertrophic.

The same applies for Vain lagoon (Figure 3), where trophic conditions have been increasingly deteriorating. In Vain lagoon, based on the data available [5], there may be noticed a tendency for the chlorophyll $a$ content to increase over the years, (Figure 3), resulting in eutrophication.

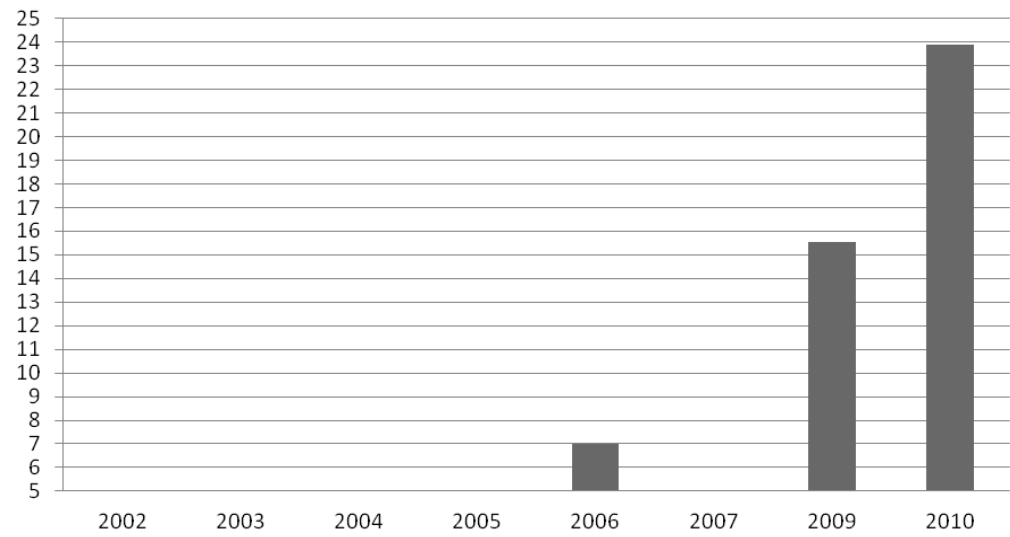

Figure 3. Variation in chlorophyll $a$ concentration in $\mathrm{mg} / \mathrm{m}^{3}$ at the Vain lagoon [5]

Based on previous data, the lagoon of Vain was characterized as oligotrophic during year 2005.

Samples collected during 2010 indicate a high chlorophyll $a$ content and the trophic state has become eutrophic, since the average chlorophyll $a$ content is $24 \mathrm{mg} / \mathrm{m}^{3}$, while in some sampling stations the trophic state appears also hypertrophic (Table 2).

Table 2. Content of photosyntethic pigments in Vain Lagoon

\begin{tabular}{ccccccc}
\hline \multirow{6}{*}{ July } & 2010 & $\begin{array}{c}\text { Chlorophyll } a, \\
{\left[\mu \mathrm{g} / \mathrm{dm}^{3}\right]}\end{array}$ & $\begin{array}{c}\text { Chlorophyll } b, \\
{\left[\mu \mathrm{g} / \mathrm{dm}^{3}\right]}\end{array}$ & $\begin{array}{c}\text { Chlorophyll } c, \\
{\left[\mu \mathrm{g} / \mathrm{dm}^{3}\right]}\end{array}$ & $\begin{array}{c}\text { Carotenoids, } \\
{\left[\mu \mathrm{g} / \mathrm{dm}^{3}\right]}\end{array}$ & $\begin{array}{c}\text { Phaeophitins, } \\
{\left[\mu \mathrm{g} / \mathrm{dm}^{3}\right]}\end{array}$ \\
\hline \multirow{6}{*}{ August } & St 1 & 3.396 & 0.628 & 0.566 & 2.603 & 0.504 \\
& St 2 & 5.663 & 0.576 & 0.66 & 3.529 & 1.59 \\
& St 3 & 6.435 & 0.83 & 1.046 & 3.991 & 2.029 \\
& St 4 & 5.893 & 0.815 & 0.968 & 4.945 & 1.432 \\
\hline \multirow{5}{*}{ September } & St 1 & 12.046 & 1.006 & 3.867 & 6.62 & 0.722 \\
& St 2 & 72.249 & 3.245 & 11.835 & 30.509 & 3.603 \\
& St 3 & 64.405 & 5.556 & 8.187 & 27.623 & 15.597 \\
& St 4 & 60.313 & 15.106 & 5.039 & 27.394 & 5.885 \\
\hline \multirow{5}{*}{ October } & St 1 & 20.374 & 0.169 & 4.361 & 13.472 & 0.217 \\
& St 2 & 28.36 & 0.122 & 3.892 & 15.625 & 0.48 \\
& St 3 & 31.495 & 0.202 & 5.552 & 16.644 & 0.226 \\
& St 4 & 15.504 & 0.115 & 2.179 & 6.895 & 0.588 \\
\hline & St 1 & 27.099 & 0.093 & 4.522 & 17.495 & 0.644 \\
& St 2 & 3.696 & 0.15 & 0.434 & 3.133 & 0.401 \\
& St 3 & 5.487 & 0.094 & 0.764 & 3.665 & 0.748 \\
& St 4 & 19.692 & 0.147 & 3.234 & 10.884 & 0.712 \\
\hline
\end{tabular}


In this lagoon, the highest trophic state during 2010 was noticed at station 3 during August $\left(72.3 \mu \mathrm{g} / \mathrm{dm}^{3}\right)$.

The distribution of pigments in the algae groups is quite unique. The kinds of chlorophylls are characteristic for each phytoplanktonic family and they can be used as potential taxonomic biomarkers of phytoplankton organisms [6].

Chlorophyll $b$ is characteristic for green algae and chlorophyll $c$ for Diatoms and Dinoflagellates; in Cyanophyceae only chlorophyll $a$ is present [7].

The distribution of chlorophyll $a$ and accessory pigments, chlorophyll $b$ and chlorophyll $c$, as well as the relative chlorophylls content (ratio of Chl " $a$ " to Chl " $b$ " and to Chl " $c$ ") exhibited differences through monitored lagoons.

In Kune Lagoon (Table 1), content of chlorophyll $c$ in the extract indicates the presence of diatoms, while presence of chlorophyll $b$ is evidence for presence of chlorophytes. Since the content of chlorophyll $\mathrm{c}$ is higher than the content of chlorophyll $b$, one can conclude that presence of diatoms is higher than presence of Chlorophytes.

In Vain Lagoon (Table 2), it can be noticed that the content of chlorophyll $b$ and chlorophyll $c$ exhibit the highest values during the month of August. In general, in this lagoon, the content of chlorophyll $c$ is higher than that of chlorophyll $b$, which again shows higher presence of diatoms.

Values of ratios between chlorophyll $a$ and chlorophyll $b$ and $c$ are high in both lagoons. These ratios keep increasing along the monitoring months.

In the Kune lagoon, during the month of July, it can be noticed that this ratio reaches higher values in Sampling station 3 compared to sampling station 1, where is also noticed a change of status from oligotrophic in station 1 to eutrophic in station 3. Values of this parameter show that the content of chlorophyll $a$ compared to chlorophyll $b$ is high in station 3, which is related to the increase in the trophic level. This indicates that the content of Cyanophyta is very high compared to two other types of microorganisms, which is also connected to the eutrophication nearby this station.

Ratios between chlorophyll $a$ and phaeophytins in both water ecosystems indicate an active state of chlorophylls.

The same conclusions can be drawn based on ratios calculated from sampling data in the two Vain sampling stations.

\section{CONCLUSIONS}

Station 2 in Vain Lagoon and station 3 in Kune lagoon are located away from respective communication channels. In these stations are also found the highest values of chlorophyll $a$ content, indicating a high trophic state.

The Kune lagoon is being transformed gradually into a site for throwing wastes. The communicating canal sea-lagoon is completely closed, thus causing a total asphyxia, especially in the summer period that is accompanied with rotting and decomposing of underwater meadows. In this period, because of the high level of evaporation, there is a significant decrease of the level of waters, a high level of eutrophication and an almost total lack of life in it [5].

The lagoon of Vain, being characterized as oligotrophic on average, during the monitoring carried out during 2010, appeared in a eutrophic state at certain stations and months (Table 2). Although it was expected that the trophic state should be better in channels 1 and 4 of Vain lagoon, this was partly true. Trophic state in sampling station 1 of Vain lagoon appeared in a better state compared to other stations, but sampling station 4 that is near the communication channel with the river, at certain months was hypertrophic (Table 2). 
This situation requires taking measures for improving circulation of waters, communication with the sea, as well as reducing urban wastes. The factors that may have contributed to the eutrophication of this lagoon are not so obvious. However, it must be emphasized that the communication canals in the Vain lagoon are mostly blocked or in a poor state.

Other factors that may impact the trophic state are population dynamics, increase of agricultural runoff, development of tourism activities, including increase in number of bars and restaurants, lack of waste management in the surrounding area, etc.

Different factors may have contributed to the deterioration of the water quality in these lagoons. In order to draw conclusions on how these factors have directly or indirectly impacted the water quality of this ecosystem, further studies are needed.

\section{RECOMMENDATIONS}

The Drini river that divides the two lagoons has an intensive sediment flow, causing changes in the coastal dynamics over the years. This process is still going on, causing the reduction in communication between the Kune lagoon and the sea. Because of circulating current of the side spreading of waves, powerful erosion has developed in the area of coast, which lies to the north of Kune, where besides vegetation of pine trees, the roadway is also being damaged.

Although there is no change in the Vain coastline due to sediments being deposited mainly towards north where Kune lagoon is, the communication canal between this river and the Vain lagoon is not sufficient to ensure good circulation of water. Even the Zaje-Drin canal, the one that connects the Vain lagoon with the Drini river near its delta, is partly blocked and does not ensure sufficient circulation. The Vain lagoon communicates with the sea through the Matkeqe canal, but it is recommended that a new canal be opened north to the existing one, since this lagoon is rapidly reaching high levels of eutrophication.

Based on this study, it results that without immediate measures, no improvement in the water quality of the lagoons will take place naturally.

Threats to the quality of the lagoons include:

- Eutrophication as a result of the reduction of water resources, discharge of sewage water directly to the lagoon, including agricultural run off;

- Reduction in exchange between the sea and the lagoon;

- Reduction and change of water regime of the lagoons as a result of construction of dams along the river deltas;

- Increase in salinity;

- Erosion;

- Uncontrolled population increase ;

- Increased tourism activity;

- Intensification of agricultural activities and as a result increase in nutrient flow.

Proposed measures for improving the situation are several. However, given the specific study, the following measures are recommended:

- Investment in maintenance of canals that connect the lagoon to the sea, especially in Vain lagoon, where there is higher eutrophication;

- Reduction of sewage water discharge, as well as agricultural runoff, limit use of organic or chemical fertilizers nearby the lagoons;

- Evaluation of the impact of different interventions, such as urban growth, increase of pollution or constructions, maintenance of communication canals lagoon-sea; 
- Evaluation of the trophic state with the addition of new sampling sites and new indicators.

\section{REFERENCES}

1. Miho A., Kashta L., Beqiraj S., Between the Land and the Sea-Ecoguide to discover the transitional waters of Albania, Study University of Tirana, 1-462, 2013

2. Anonymous, Vleresimi i gjendjes trofike dhe cilesise se ujerave ne lagunat e ekosistemit Kune-Vain dhe ne Liqenin e Shkodres, Universiteti i Tiranes, Fakulteti i Shkencave Natyrore, Departamenti i Bioteknologjise, 2010

3. Lorenzen C. J., Determination of chlorophyll and phaeopigments: spectrophotometric equations, Limnol. Oceanogr., 12, 1967

4. Carlson R. E., Simpson J., Coordinator's Guide to Volunteer Lake Monitoring Methods, North American Lake Management Society: 1-96. 1996, (http://dipin.kent.edu/tsi.htm).

5. Jeffrey S. W., Humphrey G. F., New spectrophotometric equation for determining chlorophyll a, b, c1 and c2, Biochem. Physiol. Pflanz., 167, pp 194-204. 1975

6. Schlüter, L., Mohlenberg, F., Havskum, H. \& Larsen, S., The use of phytoplankton pigments for identifying and quantifying phytoplankton groups in coastal areas: testing the influence of light and nutrients on pigment/chlorophyll-a ratios, Marine Ecology Progress Series [Mar Ecol Prog Ser], 192, pp 49-63, 2000, http://dx.doi.org/10.3354/meps192049

7. Hill, R., Wittingham, C.P., Photosynthesis, Edition 2, Publisher Methuen \& Company Limited, 1957 